\title{
Wegener 肉芽腫症に対するサイクロスポリンAの使用経験
}

\author{
深瀬滋・木村洋・坂田謙 \\ 太田 伸男・青柳優・小池 吉郎 \\ Treatment of Wegener's Granulomatosis with Cyclosporin A \\ Shigeru Fukase, Yo Kimura, Ken Sakata, Nobuo Ota, \\ Masaru Aoyagi and Yoshio Koike \\ (Yamagata University)
}

\begin{abstract}
Two patients with Wegener's granulomatosis not sufficiently reacting to predonisolone and cyclophosphamide therapy were treated with cyclosporin A (CSA). CSA was effective in both patients, and remission was sustained. Both patients continued to receive CSA for more than 2 years. Type B hepatitis was noted as a side effect of CSA in one patient, but was completely cured by interferon $\alpha$ within 4 months without stopping the administration of CSA. No other severe side effects could be detected in either patient. CSA was thus concluded to be an effective and safe drug for patients with Wegener's granulomatosis.
\end{abstract}

Key words: Wegener's granulomatosis, cyclosporin A, immunosuppressive therapy

\section{はじめに}

Wegener 肉芽腫症 (WG) は原因不明の肉芽 腫性血管炎を本態とする疾患であり，耳鼻科的 には鼻壊疽が最も大きな特徴である.種々の免 疫異常が認められることから, 従来から病因と して自己免疫が想定されてきた1)。加えて近年, WG を特徵づける自己抗体として「好中球細 胞質抗体」の存在が知られるようになり2) 5), 自己免疫疾患としての位置付けがより明確にな ってきた，一方，サイクロスポリン $\mathrm{A}(\mathrm{CSA})$ はノルウェーの土壌より分離された 2 種類の真 菌の代謝産物から精製された抗生物質であるが， その免疫抑制作用が注目され，1978年頃から免 疫抑制剤として使用されるよらになった薬剤で ある。日本に打いては1986年に発売になってお り，本剤によって腎をはじめとする各種移植の
成績が著しく向上したことは周知のと括りであ る ${ }^{6)}$. 当然, CSA の自己免疫疾患に対する効果 も期待され，種々の試みが行なわれている．特 にベーチェット病の眼病変に対する効果は確立 されたものになっている778)，本剤をWGの治 療に用いる試みも少しずつなされているが，現 在のところ本剤をWG に用いた文献的報告は 我々の調べた範囲では 3 つの施設からの報告の みであり，すべて外国のものである ${ }^{91212}$ 。我 々は, WG 2 例に対してステロイド剂と共に CSAを用いることにより，比較的良い成績を 得たので報告する.

\section{症例}

症例 1 14歳男性.

主訴：右眼球突出・鼻閉・呼吸困難.

既往歴・家族歴：特記すべきことなし。 
現病歴：昭和62年10月，右顔面痛・鼻閉出現. 11月，右眼球突出・発熱が出現，しだいに息苦 しさを覚えるようになった．11月18日当院内科 初診, CT にて右眼窩・両副鼻腔に陰影が，胸 部X線写真（図 1 ）にて右肺下葉胸膜付近に結 節状陰影が認められ当科を紹介された.

初診時現在：右眼球突出・右眼球運動障害 （外転・上転障害）を認めた。鼻内に高度の壊 死・痂皮形成を認めた。

入院時検査所見：血沈の充進, CRP の陽性, ケグロブリンの高值などが認められた（表 1 ）。 鼻腔内からの生検では「肉芽組織」との診断で あり，気管支ファイバー下での肺肉芽腫からの 生検では「肉芽組織であり, Wegener 肉芽腫 症に矛盾しない」との病理所見であった（図2）。

治療経過（図 3 ）：WG と診断し，プレドニ ゾロン (PSL) 50 mg/日，サイクロフォスファマ イド (CY) $100 \mathrm{mg} /$ 日の経口投与を開始した。 し かし，鼻内の壊死傾向は改善なく，眼球突出都 悪化した（図 4 ）。そのため，昭和63年 2 月よ

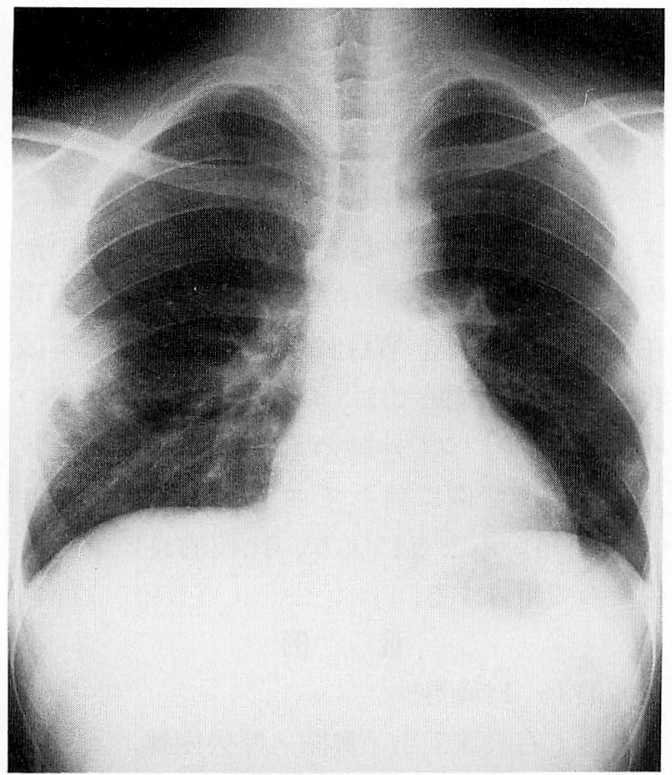

図 1 症例 1 の胸部 X線写真 右肺野に結節状陰影が認められる。
り，CY に変えて CSA の投与を開始した。 $\mathrm{CSA}$ は経口投与 (サンデミューン内用液 $\left.{ }^{\mathbb{R}}\right)$ で 用い，骨䯣移植等で用いられる方法に準じて， 初回投与量は $5 \mathrm{mg} / \mathrm{kg} /$ 日とした。 その後血中 濃度を定期的に測定し，血中濃度がトラフレベ ルで 50〜 200 ng/ml(血清法) になるように投 与量を調節した。 CSA 使用開始後 3 カ月ごろ から，鼻内の壊死傾向 ・眼球突出が改善し，昭 和63年10月退院となった。その後は，外来通院 にて CSA の投与を続け，投与開始加ら 3 年 3 カ月になるが，問題となる副作用等は認められ ていない，退院後は CSA の内服を続けながら 高校に通学している。

症例 245 歳男性, 会社員.

主訴：頭痛・膿性鼻汁.

既往歴：昭和 52 年右顔面神経麻痺（治癒）.

家族歴：特記すべきことなし。

現病歴：昭和 63 年 8 月，咳・胸痛・発熱出現.

表 1 入院時検査所見（症例 1 ）

WBC 6700 (PMN 60\%, Lym 25\%, Mo 15\%)

RBC 450万, Hb $12.1 \mathrm{~g} / \mathrm{dl}$, Plt 34.2 万

TP $8.2 \mathrm{~g} / \mathrm{dl}$, Alb $3.7 \downarrow$, A/G $0.82 \downarrow$

GOT 15, GPT 10, LDH 209

BUN 11, Crt 1.2, CRP 1.2 $\uparrow, \mathrm{RA}<8$

IgG $2775 \uparrow, \operatorname{IgA} 443 \uparrow, \operatorname{IgM} 100$

血沈 $60 / 112 \uparrow$, 尿所見異常なし

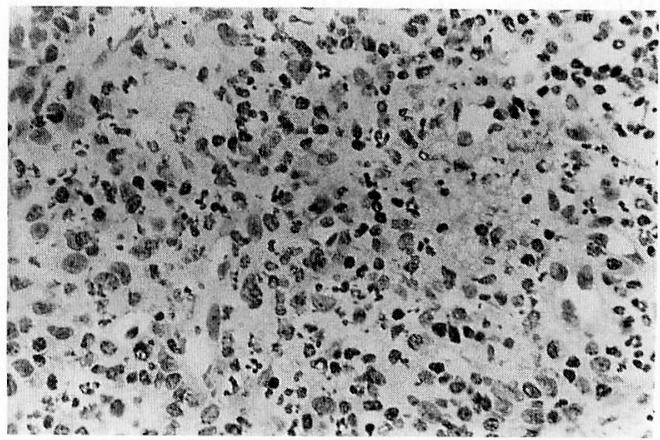

図 2 病理所見 (症例 1 )

好中球などの炎症細胞浸潤を伴ら肉芽組織が認め られる。 
胸部X線写真にて結節状陰影女り,「肺化膿症」 として他院内科入院. 抗生剂等の治療をうける も改善悪く, WG も疑い同院耳鼻科併診とな ったが，その時の鼻内所見は正常であった．試 験的に PSL $30 \mathrm{mg} /$ 日を使用したところ肺結節
陰影は改善し退院となった。この時点では確定 診断不能であった。同年11月，激しい右顔面痛 出現，当科を受診した。鼻X線にて副鼻腔炎の 所見を認め, 鼻内の高度の壊死傾向を認めた。

胸部X線写真にて, 肺に結節状陰影を認めた(図
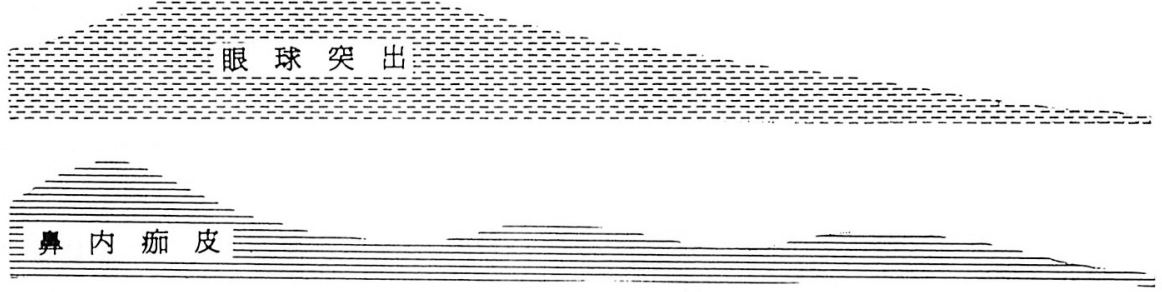
$A / G \quad 0.82 \quad 0.97 \quad 1.3$
1.17
1.25
1.74

CRP 2+ 1+ 1+

血沈 $60 / 112$

$12 / 33$

$24 / 67$

$13 / 37$

$10 / 20$
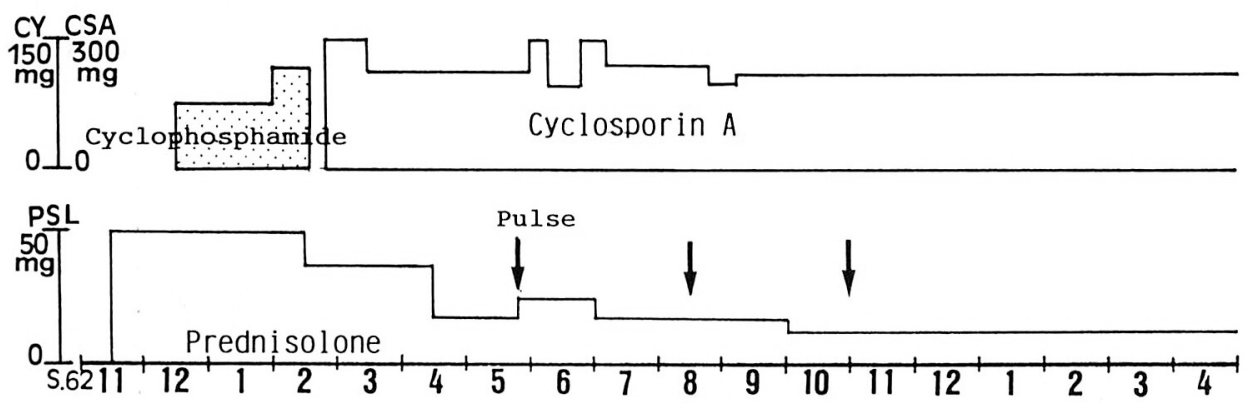

図 3 臨床経過（症例 1 ）

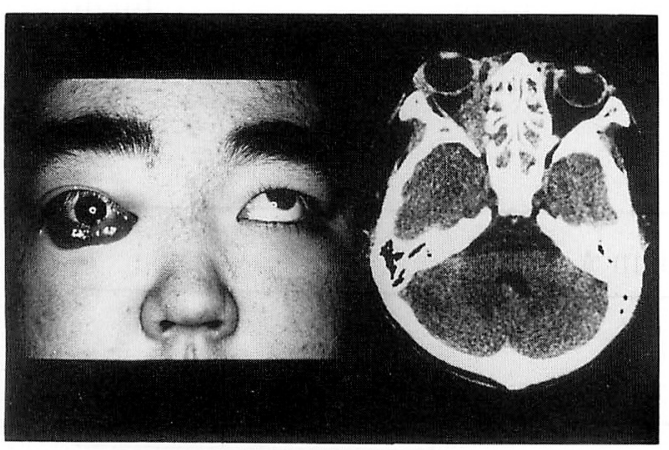

図 4 症例 1 に扮新眼症状

右眼球運動障害および眼窩内腫瘤増大に伴ら結膜 浮腫が認められる.

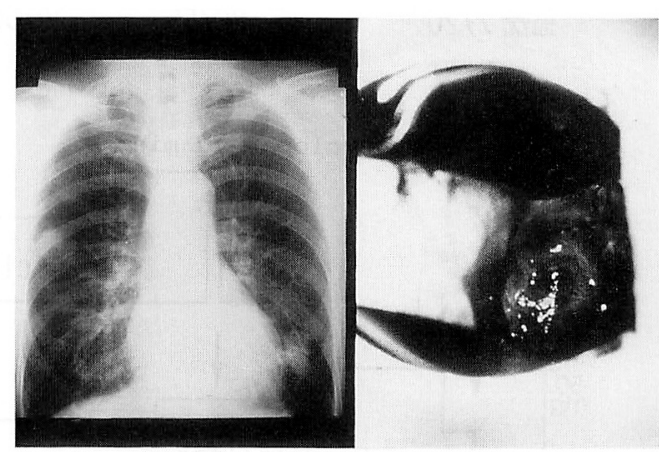

図 5 症例 2 の臨床所見 (左 ; 胸部 X線写真, 右; 下甲介部の壊死) 
5 ). WG の疑いとして, 平成元年 1 月 4 日, 当科入院となった.

入院時検查所見: CRP, RA の高值が認めら

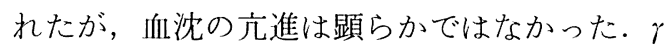
グロブリンは正常上限であった（表 2 ）。鼻内 から数回生検を繰り返したが，いずれも「肉芽 組織」との病理診断であった。（後に, 初診時 の保存血清を検査したところ抗好中球細胞質抗 体が陽性であった.)

治療経過（図 6)：本症例は，まずステロイ

表 2 入院時検査所見（症例 2 ）

WBC 7500 (PMN 61\%, Lym 33\%, Mo 6\%) RBC 365万 $\downarrow, \mathrm{Hb} 11.1 \mathrm{~g} / \mathrm{dl}$, Plt 29.5万

T.P. $7.3 \mathrm{~g} / \mathrm{dl}$, Alb $3.8 \downarrow$, A/G $1.09 \downarrow$ GOT 26, GPT 30, LDH 254

BUN 15, Crt 0.8, CRP 2.1 1 , RA $39 \uparrow$

$\operatorname{IgG} 1559, \operatorname{IgA} 260, \operatorname{IgM} 150$

血沈 7/20, 尿所見異常なし ドの単独使用（パルス療法：methylprednisolone $1000 \mathrm{mg} /$ day 3 日間, その後 PSL 内服 50 $\mathrm{mg} /$ 日）を行なった．胸部結節状陰影はこの治 療にて消失したが頭痛は増悪してきたため, CY と PSL の併用療法に変更した。しかし， 頭痛の改善得られず，平成元年 5 月 CSA と PSL の併用に変更した. CSA の使用量は症例 1 に準じた。本症例において CSA 開始後, 同 剂服用直後に「顔面のほてり」の訴觉があった。 しかし，3 カ月程度で訴えは自然に消失した。 その後徐々に諸症状の改善が得られ，鼻内の壊 死傾向も改善してきた. 平成元年 9 月退院, 外 来で CSA の投与をつづけ, PSL も減量中であ る. 本症例は外来治療中 (CSA 投与開始後, 8 力月目頃） B 型肝炎が発症し, GOT 及び GPT は最高 $500 \mathrm{IU} / 1$ 台まで上昇した。しかし， インターフェロン $\alpha \quad(300 \mathrm{IU} \cdot 2$ 回/週・6 力月 間）の筋注投与で外来通院のまま transaminase 值の正常化が得られ，CSA の投与は
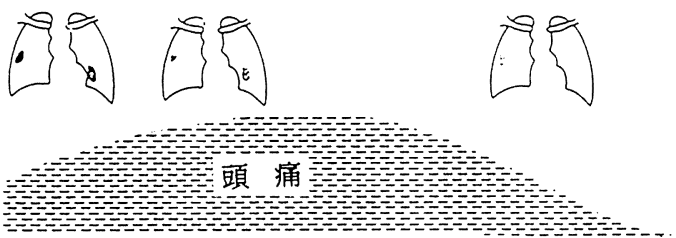

$\begin{array}{llllll}A / G & 1.09 & 1.3 & 1.35 & 1.45 & 1.35\end{array}$

CRP 2+ $1+1+1+1+$

血沈 7/20

$20 / 55$

$20 / 50$

$10 / 19$

$10 / 20$
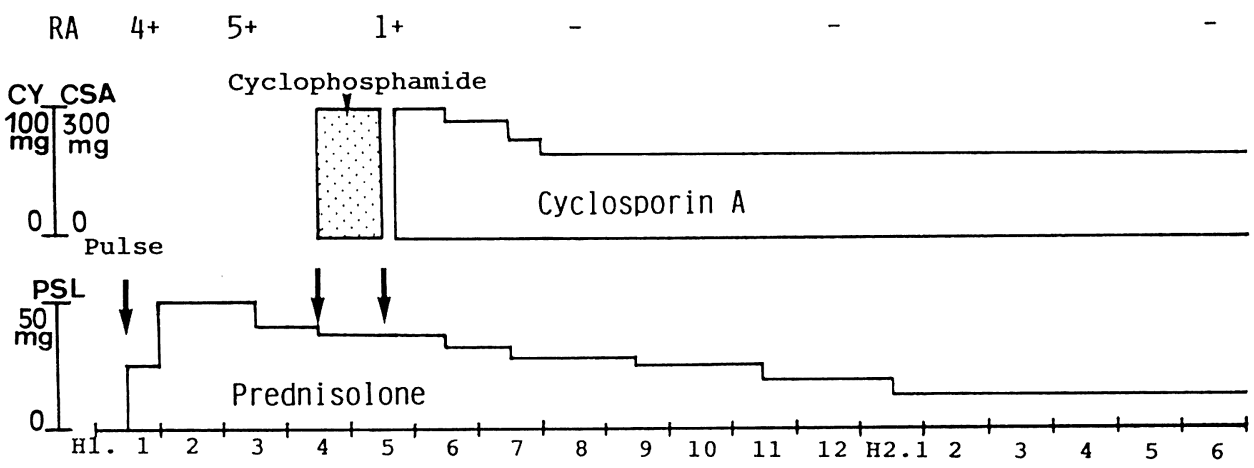

図 6 臨床経過（症例 2 ） 
継続した. 本症例は現在まで, 約 2 年 CSA の 投与を続けている.

\section{考 察}

WG は免疫抑制剤による治療が確立される 前は極めて予後の悪い疾患とされ，未治療の場 合は 1 年以内に $80 \%$ が， 2 年以内に $90 \%$ が死亡 するとも，6カ月以内に $100 \%$ が死亡するとも 言われていた。しかし，免疫抑制剤を治療に用 いるよらになってその治療成績は著しく改善し た. 特に, Fauci ら12) によりステロイド剤と CY の併用療法が広く用いられるようになって, 5 年以上の生存例も数多く報告される様になっ てきた12) 15). しかし, 炎症の一時的な沈静化 が行なわれても,なかなか完全治瘉は望めない のが現実である. 眼窩内肉芽のために失明した り, 鞍鼻などの醜形を残したり, 声門下肉芽の ために気管切開を余儀なくされたり，慢性透析 を必要としたりと本疾患の治療に関する問題点 は多い，皮肉なことに，鼻腔内の構造物が破壊 し尽くされると病勢も下火になるよらである。 我々は, PSL 及び CY 併用療法で十分な改善 の得られなかった難治性 WG 2 症例に対し,

CSA を使用し外来通院治療に移行することが できた。この経験から CSA はWGの治療に非 常に有効な薬剤であるとの感触を得た. しかし, 2 例とも現在のところ完全に薬物から離脱でき た訳ではなく，根治性があるか否かに関しては まだ結論は出せない。

副作用に関しては, 症例 2 において CSA 投 与後にB型肝炎の発症が認められた. 経過から 考えて，これは CSAの免疫抑制作用に基づく
ウイルスの活性化による可能性が考え易い。し かし，本症例では本剤を中止することなく，イ ンターフェロン $\alpha$ の投与で肝炎を治癒させる ことができた，又，同じ症例 2 において CSA 投与初期に同剤服用直後に「顔面のほてり」の 訴えがあったが， 3 力月程度で訴えは自然に消 失した。症例 $1 \cdot 2$ とも 2 年以上の長期にわた って，CSAの投与を続けているが，これ以外 の問題になる副作用は無く, 予想以上に安全に 用い得る薬剤であるとの印象であった．

現在までに我々が集め得たWGに対する CSA に上る治療の文献的報告は表 3 に示した 様に 3 件のみであり (9) -11), WGに合併した角 膜潰瘍に対する CSA 治療16)に関するものを加 えても 4 件のみである.いずれも我々と同様に ステロイド剤との併用で有効性が報告されてい る. 副作用は, 軽度の血清クレアチニン上昇が 報告されているのみである。CSA の本疾患に 対する投与方法・投与量などは報告者によりま ちまちであり，これからの課題であろら。 $\mathrm{CSA}$ の作用機序は次々と新しい作用点が明ら かにされてきており，まだ全てが解明されてい る訳ではないが，少なくとも T細胞系に対する 作用を持っていることは確かであるＷGは 最近, 疾患標識抗体として抗好中球細胞質抗体 の存在が顕らかになってて2 〜5), その病因との関 係が注目されてきている.WG 患者末梢血中 に好中球細胞質抗原に特異的に応答する $\mathrm{T}$ 細胞 があるとの報告もあり ${ }^{17)}, \mathrm{CSA}$ がこのT細胞群 を抑制していると考えれば理解は容易であるが， 今後更に検討していかなければならない。

表 3 Wegener 肉芽腫症に対するサイクロスポリン A 治療の報告

\begin{tabular}{ccccl}
\hline \hline 報告者 & 詨 照 & 投与量 & 効 果 & 副作用 \\
\hline Grammel(1988) & 45歳男 & $5 \mathrm{mg} / \mathrm{kg}$ & 著 效 & 記載なし \\
& 58 歳女 & $5 \mathrm{mg} / \mathrm{kg}$ & 著 効 & 記載なし \\
Borleffs (1987) & 60 藏男 & $10 \mathrm{mg} / \mathrm{kg}$ & 有 効 & Crt 軽度上昇 \\
Kruit(1985) & 56歳男 & $10 \mathrm{mg} / \mathrm{kg}$ & 有 効\# & なし
\end{tabular}

\#WGに合併した角膜㵅瘍に対して有效 


\section{結語}

WG 新鮮例に対しては，まず多くの治療実 績報告からみて Fauci らの PSL・CY 併用療法 を試みるべきと思われるが，これで一定期間治 療して改善の認められない症例に対しては， CSA を用いるのもひとつの方法であろうと考 えられた，我々の使用経験からも CSA は十分 な監視下で用いる場合，「安全・有効な薬剤」 であり，外来通院中の投与も問題なく行なえる ものと思われた。

\section{参考文献}

1) Wegener $F$ : Wegener's granulomatosis; thought and observations of a pathologist. Eur Arch Otorhinolaryngol $247:$ 133 142, 1990.

2) Woude FJ, Rasmussen N, Lobatto S, et al : Autoantibodies against neutrophils and monocytes ; tool for diagnosis and marker of disease activity in Wegener's granulomatosis. Lancet $1: 425 \sim 429,1985$.

3）吉田雅治, 斉藤元章, 長沢俊彦: Wegener 肉 芽腫症に括忷る好中球細胞質に対寸る自己抗体 の研究. 日内会誌 $78: 1581 \sim 1585,1989$.

4) 深瀬 滋, 小池吉郎：ウェジェナー肉芽腫症患 者血清中の抗好中球細胞質抗体一診断及び活動 性の評価に拈ける重要性一.耳鼻免疫アレルギー $9: 74 \sim 79,1991$.

5) Leaker B and Cambridge G : Anti-neutrophil cytoplasmic antibodies and vasculitis. Postgrad Med J $66: 77 \sim 79,1990$.

6）正岡 徹：サイクロスポリンAの作用機序と臨 床応用. 一骨髄移植を中心として一. 臨床免疫 $17: 104 \sim 110,1985$.

7）宮坂信之：自己免疫疾患治療の現状と展望. 臨 床免疫 $21: 868 \sim 879,1989$.

8）望月 學：シクロスポリンによる自己免疫病の
治療. 臨床免疫 $20: 75 \sim 83,1988$.

9) Borleffs JCC, Derksen RHWM and Hene RJ : Treatment of Wegener's granulomatosis with cyclosporin. Ann Rheum Dis 46 : 175, 1987.

10) Borleffs JCC, Derksen RHWM and Hene RJ : Wegener's granulomatosis and cyclosporin. Transplant Proc $20: 344 \sim 345,1988$.

11) Gremmel F, Druml M, Schmidt P, et al : Cyclosporin in Wegener's granulomatosis. Ann Intern Med 108 : 491, 1988.

12) Fauci AS, Haynes BF, Katz $P$, et al : Wegener's granulomatosis : prospective clinical and therapeutic experience with 85 patients for 21 years. Ann Intern Med $98: 76 \sim 85,1983$.

13）長沢俊彦, 吉田雅治 : 免疫異常・アレルギーの 治療一ウェゲナー肉芽腫症一. 綜合臨床 37 : 2809〜2815, 1988.

14）渡部泰雄：今日の耳鼻咽喉科/治療のコツと全 身管理一Wegener 肉芽腫症一。耳喉 50:787 $\sim 789,1978$.

15）渡部泰雄：ステロイド剂の適応と使い方ゥェゲ ナ一肉芽腫症・進行性鼻壊疽. JOHNS 5:197 $\sim 201,1989$.

16) Kruit PJ, Vanbalen ATM and Stilma JS : Cyclosporin A treatment in two cases of corneal peripheral melting syndrome. Doc Ophthal Med $59:$ 33 39, 1985.

17) Woude FJ, Es LA and Daha MR : The role of c-ANCA antigen in the pathogenesis of Wegener's granulomatosis; a hypothesis based on both humoral and cellular mechanisms. Neth J Med 36 : 169 171, 1990.

$$
\left(\begin{array}{l}
\text { 別刷請求先 : 深瀬 滋 } \\
\text { 干990-23 山形市飯田西2-2-2 } \\
\text { 山形大学医学部耳鼻咽喉科学教室 }
\end{array}\right)
$$

